\title{
VI МЕЖДУНАРОДНАЯ НАУЧНО-ПРАКТИЧЕСКАЯ КОНФЕРЕНЦИЯ «ЭКОЛОГИЧЕСКАЯ ГЕОЛОГИЯ: ТЕОРИЯ, ПРАКТИКА И РЕГИОНАЛЬНЫЕ ПРОБЛЕМЫ»
}

\author{
И. И. Косинова \\ Воронежский государственный университет \\ Поступила в редакцию 24 сентября 2019 г.
VI INTERNATIONAL SCIENTIFIC-PRACTICAL CONFERENCE «ENVIRONMENTAL GEOLOGY: THEORY, PRACTICE AND REGIONAL PROBLEMS»

\author{
I. I. Kosinova \\ Voronezh State University \\ Received 24 September 2019
}

15-18 сентября на площадке Севастопольского государственного университета состоялась VI международная научно-практическая конференция «Экологическая геология: теория, практика и региональные проблемы». Данная конференция проводится в формате мобильных площадок. Первые заседания проходили на площадке Воронежского государственного университета, четвёртая - в геологическом институте Кольского филиала академии РАН, пятая и шестая - в Севастопольском государственном университете. Отличительными особенностями шестой конференции являются:

- проведение её в пятилетнюю годовщину присоединения Крыма к России. Следует отметить значительное преобразование Крыма за последние годы, что проявляется в активизации нового строительства. Это новые дороги, жилые микрорайоны, универсальный аэропорт «Айвазовский» и многое другое;

- новации 2019 года заключаются в расширении состава титулодержателей конференции. В настоящее время в него вошли Московский, Воронежский, Севастопольский государственные университеты, Воронежский государственный технический университет, Вьетнамский национальный университет, Российская экологическая академия. Образовавшийся союз учёных и преподавателей ВУЗов позволил расширить спектр рассматриваемых проблем, актуализировать разработку схем рационального природопользования;

- широкий спектр образовательного и научнопроизводственного направления участников. Среди них представители 19 ведущих ВУЗов России и зарубежья, 17 научно-исследовательских институтов и центров, 6 производственных компаний;

- география участников конференции представлена практически всеми регионами Российской Федерации, вузами Белоруссии и Вьетнама.

Участники конференции в представленных докладах рассмотрели вопросы теории и методологии экологических направлений в различных сферах подготовки специалистов, теоретических основ экологических функций литосферы, практических методов реализации инновационных экологических разработок.

Пленарное заседания было открыто докладом д.гм.н, проф. Трофимова В. Т., посвященным особенностям исследования абиотических и биотических компонентов природной среды в условиях значительных техногенных нагрузок. В целом Пленарное заседание объединило серию докладов ведущих учёных Московского, Воронежского, Севастопольского университетов, представителей научных организаций Архангельска, Новосибирска, Дубны.

Секция «Экологические функции литосферы и их трансформация в эпоху техногенеза» была представлена докладами, отражающими оценки и закономерности трансформации экологических функций литосфера в результате селитебного, рекреационного сельскохозяйственного, водохозяйственного, горнопромышленного освоения территории. В качестве ведущих факторов влияния рассматривались: кадмиевое, ртутное, селеновое загрязнение, особенности

(C) Kosinova I. I., 2019

Контент доступен под лицензией Creative Commons Attribution 4.0 License.

The content is available under Creative Commons Attribution 4.0 License. 
формирования эколого-геофизических аномалий. Большой интерес вызвал доклад И. И. Косиновой, посвящённый роли геологических парков в сохранении экологического благополучия территории.

Секция «Проблемы техносферной безопасности территорий, охраны труда, техногенные и экологические риски» свою работу направила на анализ физических и химических воздействий, характеризующих воздействие отдельных предприятий на комфортность среды жизнедеятельности. Ряд технических докладов был посвящён технологиям аэро- и космических дистанционных методов исследований конкретных природных и техногенных ситуаций. Также обсуждались вопросы инновационных технологий переработки твёрдых коммунальных отходов, проблемы экологогеологического мониторинга, отдельных ГИСпроектов. Работа секций была продолжена в формате студенческого круглого стола.

Секция конференции, рассматривающая экологические последствия практическо-хозяйственной деятельности в геосферах, представила работы, география которых изменяется от Японского моря, промпредприятий Карабаша до Крыма.

Особенности инженерных изысканий на техногенно-нагруженных территориях были рассмотрены в рамках четвертой секции. Большой интерес вызвали доклады, касающиеся методических основ выделения границ территории инженерных изысканий. Данная проблема была предметом обсуждения в серии конференций, посвященных инженерным изысканиям. Это связано с дифференциацией подходов при обосновании границ площадей различных видов изысканий, в особенности - инженерно-экологических.

Методические проблемы проведения инженерных изысканий также обсуждались применительно к определению радоноопасности территорий. Практическое значение имели доклады, касающиеся опыта выполнения инженерно-экологических изысканий при реализации отдельных проектов.

Секция 5 объединила научные изыскания молодых ученых. Самым юным участником работы секции стал ученик МБОУ СОШ Гимназия №1, г. Воронеж Курбатов Герман. Его работа была посвящена экологическим последствиям климатических аномалий в пределах городской агломерации г. Воронежа. Особенности составления экологической карты родников Севастопольского региона были представлены в работах учеников 11 класса школы №3 г. Севастополя

ФГБОУ ВО Воронежский государственный университет

Косинова Ирина Ивановна, доктор геолого-

минералогических наук, профессор, заведующий кафедрой экологической геологии

E-mail:kosinova777@yandex.ru

Тел.: +7 (473) 2208289
Одинцова Михаила и Ездакова Никиты. В целом в работе молодежной секции приняли молодые ученые из Воронежа, Севастополя, Ханоя, Москвы, Сыктывкара, Саратова и др.

По результатам обсуждения обозначенных вопросов научное сообщество, объединенное VI международной научно-практической конференции «Экологическая геология: теория, практика и региональные проблемы», сформулировало следующие предложения:

1. Расширить количество направлений в образовательной практике по направлению «Геология». Конференция считает целесообразным открытие направления «Экологическая геология», что обусловлено особенностями целей, задач, объекта и предмета эколого-геологических исследований, спецификацией трудоустройства выпускников.

2. Активизировать методологическое обоснование систем эколого-геологического мониторинга на основе эффективных решений и инновационного оборудования. Конференция считает целесообразным сообщить о необходимости принятия срочных мер по восстановлению в Республике Крым службы мониторинга, отслеживающей состояние компонентов природной среды, гидротехнических сооружений.

3. Поддержать опыт Воронежского и Севастопольского университетов по работе со школьниками в формате выполнения научно-исследовательских работ экологического направления. Привлекать участников проектов к участию в международных научнопрактических конференциях, что позволяет молодым участникам знакомиться с результатами новейших научных исследований.

4. Среди представленных направлений развития эколого-геологических исследований следует отметить разработку методов эколого-геологических оценок, построения систем оптимального состояния абиотических и биотических компонентов природной среды, разработку комплекса профилактических мероприятий, направленных на сохранения благоприятных эколого-геологических обстановок, улучшения состояния зон экологического риска и кризиса.

5. Разработать научно-методическое обоснование создания сети геологических парков в России. Поддержать идею создания Донского геологического парка как основы экологического каркаса территории, места реализации образовательных, научно-исследовательских и туристических проектов.

Voronezh State University

Kosinova I. I., Doctor of Geological and Mineralogical Sciences, Professor, Head of Environmental Geology Department

E-mail:kosinova777@yandex.ru

Tel.: +7 (473) 2208289 